\title{
Characterization of preimaginal developmental stages in Africanized honey bee workers (Apis mellifera L)
}

\author{
ER de F Michelette, AEE Soares *
}

Department of Genetics, Faculty of Medicine of Ribeirao Preto, 14049-900 Ribeirao Preto, SP, Brazil

(Received 24 January 1992; accepted 20 April 1993)

Summary - The stages of preimaginal development of the Africanized worker honey bee (Apis mellifera $L$ ) were characterized. Body weight and head diameter were used as characters with which to differentiate among the first 4 instars, and additional traits such as apolysis, defecation and tibiotarsal length of the hind legs were used to characterize the subdivision of the 5 th and last instar. $\mathrm{Pu}$ pal stages were determined on the basis of eye and thorax pigmentation. The duration of each stage was also determined from these characteristics. The post-embryonic development period of Africanized bees is $\approx 24 \mathrm{~h}$ shorter than that in Apis mellifera carnica, and 18 and $24 \mathrm{~h}$ longer than in African bees.

Africanized honeybee / preimaginal development / duration of development / larval instar

\section{INTRODUCTION}

Like other holometabolic insects, honey bees present 3 different phases (larva, pupa and adult), separated by metamorphic moults. The larval phase is mainly a period of feeding and growth. The end of this phase is marked by the beginning of metamorphosis, which consists of a complex reorganization of larval structures and the formation of imaginal structures. After pupal ecdysis, the pupa undergoes a series of changes in the pigmentation of the compound eyes and of the body. The pu- pal/imago moult occurs at the end of this phase.

Several investigators have described the preimaginal development of Apis mellifera $L$ using European honey bees (Nelson, 1924; Bertholf, 1925; Myser, 1954; Rembold et al, 1980; Thrasyvoulou and Benton, 1982). The presence of 5 larval instars has been determined by these studies and the final larval instar has been subdivided according to the dramatic changes occurring in it (Rembold et al, 1980; Rachinsky, 1990). Several stages have also been observed in the pupal phase.

\footnotetext{
* Correspondence and reprints
} 
However, the duration of these stages varies among different bee races such as the Europeans, Africans and their hybrids (Africanized) (Kerr et al, 1970; Garofalo, 1977; Tribe and Fletcher, 1977; Fletcher, 1978; Palacio, 1991). When the duration of the post-embryonic development stages of Africanized and European bees were compared in a common environment, differences were also found (Rosenkranz, 1990; Palacio, 1991). In contrast, Morini (1990) observed similar duration of postembryonic stages in a study comparing European and Africanized honey bees.

Nevertheless, a detailed characterization of the developmental phases has not been available for Africanized bees. Thus, the objective of the present investigation was to provide a detailed profile of the preimaginal development of Africanized bees using morphological and physiological characters, in order to facilitate studies in different areas in which the identification and duration of these stages are important requirements.

\section{MATERIALS AND METHODS}

The study was conducted with Africanized honey bees from the Experimental Apiary of the Department of Genetics, Faculty of Medicine of Ribeirao Preto, University of Sao Paulo, Ribeirao Preto, SP, Brazil $\left(21^{\circ} 11^{\prime} 25^{\prime \prime}\right.$ latitude $S$ and $47^{\circ} 43^{\prime} 04^{\prime \prime}$ longitude $W$ ). The bees were maintained in Langstroth-type hives with 10 frames containing a standardized number of bees. During periods of food scarcity, colonies were fed sucrose syrup $(60 \% \mathrm{w} / \mathrm{v})$.

In order to obtain controlled oviposition, the queen of a colony was secured to a comb with the aid of an excluder cage for a period of $6 \mathrm{~h}$. In order to reduce the disturbance to the colony during sample collection, a group of 5 colonies was used alternately. Samples were taken from each colony a maximum of once a day. Eggs were monitored beginning $60 \mathrm{~h}$ later in order to determine the precise moment of hatching. The brood combs were maintained in their original colonies and samples were collected at 6-h intervals from hatching to imago. During the larval phase, larvae were weighed and their head diameter (measured at the antennal imaginal discs) was measured using a stereomicroscope. The larvae collected before cell sealing were washed in physiological saline to remove any traces of food remaining on their bodies. During the 5th and last larval instar, the position and movement of the larva within the cell, apolysis, defecation and tibio-tarsal length of the hind legs, in addition to weight and head diameter, were used to characterize the subdivisions of this instar. The leg primordia are evident beginning at the 3rd larval instar with their respective segments (Myser, 1954). At the 5th larval instar (after cell sealing), the tibia and tarsus of the 3rd pair of legs were measured through dissection of the leg buds in physiological saline. In the prepupa these can be measured through the transparent larval cuticle. A total of 1249 larvae were analyzed. For the determination of pupal stages, the brood comb was left in the hive until the prepupal stage, when samples started to be collected at 6-h intervals. Eye colour and thorax pigmentation were classified using the international color standard of the Munsell color book (Macbeth Division of Kollmorgen Corp, Baltimore, MD, 1976).

The general conditions of the colonies were carefully maintained throughout the characterization of larval and pupal stages in order to avoid any interference with the development of larvae and pupae. Specimens were collected during various seasons in order to minimize possible environmental effects.

\section{RESULTS}

\section{Characterization of larval instars}

When a comparison was made between the log of the body weight and the diameter of the head capsule of 1249 worker larvae 5 groups become evident (fig 1), each corresponding to a larval stage. The intervals between groups represent the larval ecdyses, as determined by Brook-Dyar's rule (Hutchinson and Tongring, 1984). Ac- 


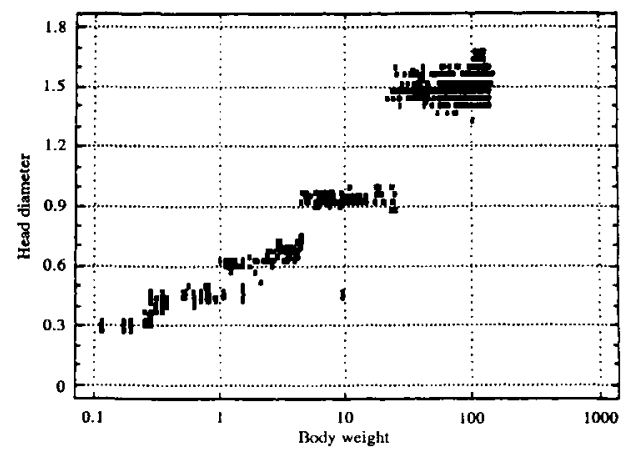

Fig 1. Correlation between body weight and head diameter. $R^{2}=0.7585$ highly significant; $P<0.01$.

cording to this rule, the number of discontinuities in a sclerotized non-articulating structure, as determined by measurements, corresponds to the number of larval instars.

Body weight markedly increases (a sigmoid curve) during the first 4 larval instars, up to the moment of sealing the larval cell (fig 2), when it decreases slightly just before the pupal ecdysis. The weight ranges and mean head diameters observed in the
5 larval instars are presented in table I, with a significant difference between the mean head diameter values $(P<0.01)$. The 5 th and longest larval instar can be subdivided into 9 periods which are marked by clearly identifiable events that distinguish several subdivisions or successive phases of the 5th larval stage. These are: 3 involving the end of the feeding phase (LF1, LF2 and LF3); 3 involving the cocoon-spinning phase (LS1, LS2 and LS3), and the last 3 correspond to the prepupal phase (PP1, PP2 and PP3). Since no easily recognizable outer changes occur during the feeding periods, the change in body weight was used as a parameter for the identification of these periods. The first subdivision (LF1) corresponds to the beginning of the last period of larval feeding after the moult to the 5th instar, with larvae weighing an average of $34.87 \pm$ $7.75 \mathrm{mg}$. Larvae weigh an average of $72.05 \pm 18.96 \mathrm{mg}$ during LF2, whereas at the end of these instar, during LS3, average larval weight is $111.32 \pm 4.54 \mathrm{mg}$. The mean larval weight during the different periods of the 5th larval instar and the prepu-

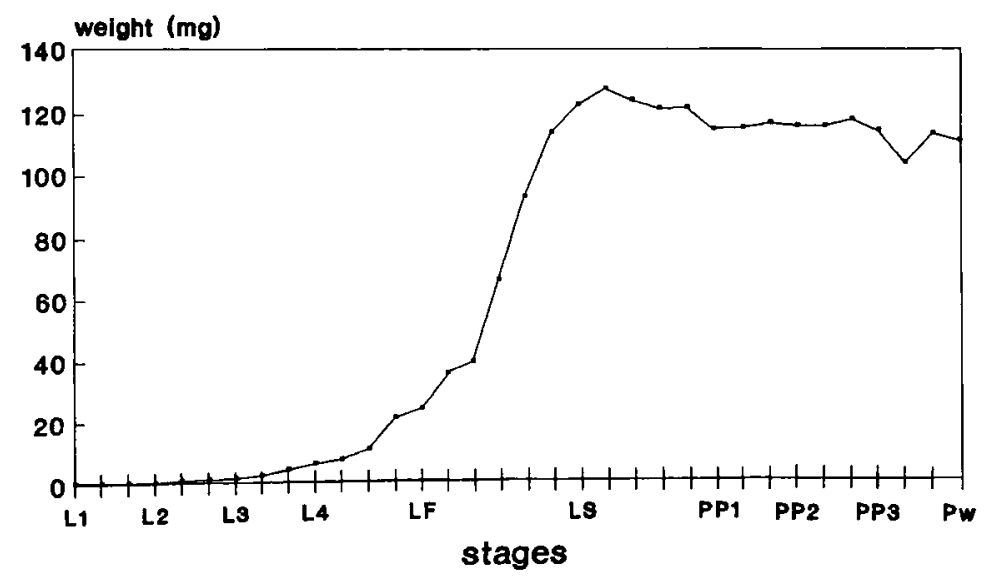

Fig 2. Mean weight of worker larvae from the first larval instar $(L 1)$ to the white-eyed pupal stage $(P w)$. 
Table I. Weight range and mean head diameters during the larval instars.

\begin{tabular}{cccccr}
\hline Instar a & $\begin{array}{c}\text { Weight }(\mathrm{mg}) \\
\text { (min-max) }\end{array}$ & $\mathrm{n}$ & $\begin{array}{c}\text { Mean head } \\
\text { diameter }(\mathrm{mm})\end{array}$ & SO & \\
\hline L1 & $0.11-0.30$ & 139 & 0.32 & 0.0256 & $\mathrm{n}$ \\
L2 & $0.31-1.05$ & 135 & 0.44 & 0.0321 & 53 \\
L3 & $1.50-4.45$ & 66 & 0.65 & 0.0451 & 59 \\
L4 & $4.80-24.8$ & 59 & 0.92 & 0.0939 & 117 \\
L5 & $24.30-126.7$ & 354 & 1.49 & 0.0475 & 121 \\
\hline
\end{tabular}

a The larval instars are symbolized as follows: $L 1-L 5=1$ st-5th larval instar; ${ }^{b} \mathrm{SD}$ : standard deviation.

Table II. Mean weights during the periods of the 5th larval instar.

\begin{tabular}{lrcr}
\hline Periods * & $\mathrm{n}$ & Weight (mg) & \multicolumn{1}{c}{ SD } \\
\hline LF1 & 121 & $34.87^{\mathrm{h}}$ & 7.752 \\
LF2 & 176 & $72.05^{\mathrm{g}}$ & 18.960 \\
LF3 & 24 & $111.32^{\mathrm{cde}}$ & 4.540 \\
LS1 & 154 & $124.21^{\mathrm{a}}$ & 7.483 \\
LS2/LS3 & 47 & $117.88^{\mathrm{b}}$ & 4.650 \\
PP1 & 130 & $113.64^{\mathrm{cd}}$ & 6.346 \\
PP2 & 105 & $112.57^{\mathrm{d}}$ & 4.755 \\
PP3 & 53 & $107.55^{\mathrm{f}}$ & 5.909 \\
\hline
\end{tabular}

* LF1-LF3 = last larval periods; LS1-LS3 = larval periods after sealing; PP1-PP3 = prepupal periods; 2) a, b. c, d. e, 1, g. I different letters in superscript indicat a statistical difference $(P<0.01)$.

pal period are presented in table II. The differences between these groups were significant $(P<0.01)$, except for LF3, PP1 and PP2. At the end of the feeding periods, the brood cells are sealed by the nurse bees. Approximately $2 \mathrm{~h}$ later, the larva starts spinning its cocoon (Rachinsky, 1990). Since cocoon spinning is difficult to detect, we considered cell sealing as one of the parameters for the determination of this new period (LS) during which the larva reaches its maximum weight. The additional parameters used were: defecation, larval position within the cell, and the length of the tibia and tarsus of the third pair of legs. At LS1, the larva is rolled up inside the cell and moves about. The intestine is completely filled with a yellowish materal; the tibio-tarsal length is 0.8 to 1.0 $\mathrm{mm}$, and does not change until the end of LS3. Defecation marks LS2, during which one-half the length of the intestine empties. At LS3, defecation terminates. The larva then extends lengthwise in the sealed cell with its head oriented toward the operculum, and becomes motionless. This marks the beginning of the prepupal period. The intestine is completely empty but is still visible in the dorsal region of the larva. The prepupa is characterized by profound morphological modifications such as the enlargement of the eyes. The antennae remain $S$-shaped but are longer and distinctly 12 -segmented. The thorax is separated from the head by a distinct constriction. An easily identifiable event is apolysis, which begins each moulting cycle (Hinton, 1973), but is more easily recognized during this period. For this reason, the progression of apolysis from the cephalic to the posterior region was also utilized to characterize the prepupal subdivisions. Apolysis begins in the head region 
and is observable as a separation of the larval cuticle from the newly forming cuticle, with the space between cuticles filled with exuvial fluid. During the 1st prepupal period (PP1), the intestine can be visualized as an empty tube, and the tibio-tarsal length is 1.20 to $1.44 \mathrm{~mm}$. At PP2, the intestine is no longer visible, and the tibiotarsal length increases to 1.80 to $2.00 \mathrm{~mm}$. When apolysis extends to the thorax and abdomen, the appendages of the head and thorax are visible through the cuticle. At the end of the prepupal stage (PP3), the exuvial fluid is reabsorbed, and the digested larval cuticle become opaque and wrinkled. The thoracic appendages are no longer visible through the larval cuticle. Ecdysis is the next step towards completion of metamorphosis.

\section{Characterization of pupal stages}

Seven pupal stages were identified during the pupal phase according to eye and thorax colour (table III).

Table III. Characterization of pupal stages.

\begin{tabular}{|c|c|c|}
\hline Stage & Pigmentation of eye & $\begin{array}{l}\text { Pigmentation of thorax } \\
\text { (dorsal mesothorax) }\end{array}$ \\
\hline Pw & White (5R 9/2)* & - \\
\hline $\mathrm{Pp}$ & Pink (10R $8 / 4$ to $10 R 5 / 4$ ) & - \\
\hline Pdp & Dark pink (10R 4/4) & - \\
\hline $\mathrm{Pb}$ & Brown (7.5R 3/4) & - \\
\hline $\mathrm{Pbl}$ & $"$ & Light $(2.5 Y 8 / 4)$ \\
\hline Pbm & $"$ & Medium (10YR $7 / 6$ to 10 YR $5 / 4$ ) \\
\hline Pbd & $" \quad(7.5 \mathrm{R} 2.5 / 2)$ & Dark (10YR 4/2) \\
\hline
\end{tabular}

* According to the Munsell Color Book. Pw = white-eyed pupae; $\mathrm{Pp}=$ pink-eyed pupae; $\mathrm{Pdp}=\mathrm{dark}$ pink-eyed pupae; $\mathrm{Pb}=$ brown-eyed pupae; $\mathrm{Pbl}=$ brown-eyed, light pigmented thorax pupae; $\mathrm{Pbm}=$ brown-eyed, medium pigmented thorax pupae; Pbd = brown-eyed, dark pigmented thorax pupae.
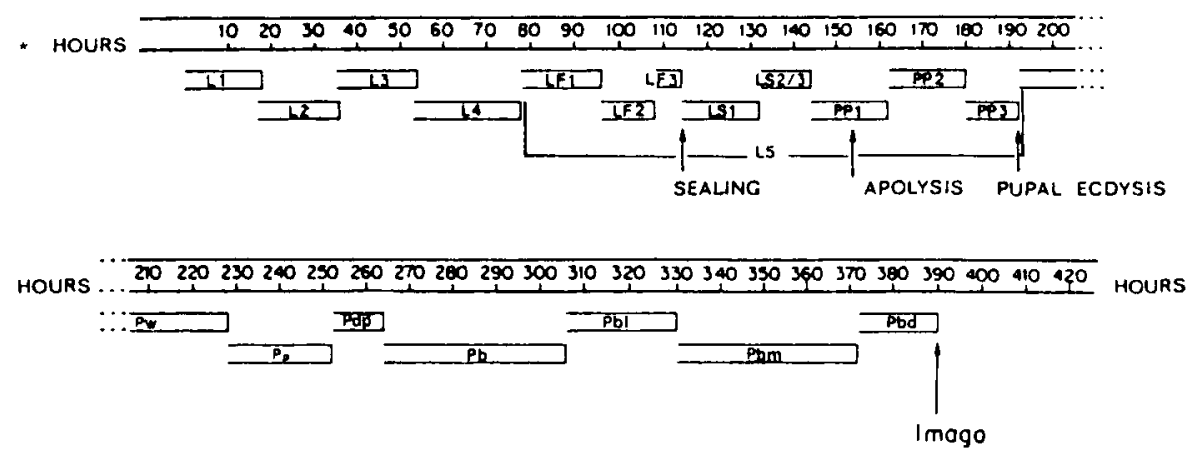

Fig 3. Duration of the stages and periods of preimaginal development, and indication of some events used to characterize these stages. * : hours after hatching. 


\section{Duration of larval and pupal stages}

The duration of the different stages and periods of preimaginal development determined on the basis of the present data are presented in figure 3. A variation of $\pm 6 \mathrm{~h}$ as well as an overlapping of some stages was observed.

\section{DISCUSSION}

According to Thrasyvoulou and Benton (1982), the growth curve of worker larvae gives a good indication that larval weight can be used as an indicator of larval age. This agrees with our results as well those of Wang (1965), Rembold et al (1980) and Rachinsky (1990) in European bees. Worker weight increases more rapidly during the first $90 \mathrm{~h}$ of development, and queen weight can vary more than worker weight (Wang, 1965). The decrease in larval weight observed here after sealing has also been reported by others in European bees (Jay, 1962; Rembold et al, 1980; Rachinsky, 1990). Weight continues to decrease gradually up to adult emergence (Jay, 1961; cited by Jay, 1963).

The first 4 larval instars can be determined in a relatively simple manner on the basis of head size and body weight. By comparing the present results with those reported by Goitein (1989) for Africanized honey bee, mean head size was found to be similar for each instar, but the mean duration was found to be longer in his material. However, our results are similar to those of Rosenkranz (1990) and Palacio (1991), with respect to the larval development in Africanized bees. Little variation in larval instar duration was found when we compared our results with those obtained for $A$ m carnica (Rembold et al, 1980). In contrast, the LF3 period for the 5th larval instar, corresponding to the time of seal- ing, is $\approx 6 \mathrm{~h}$ shorter in Africanized bees than in A m carnica (Rachinsky, 1990). Another difference is in the prepupal periods, which is $6 \mathrm{~h}$ shorter in the bees studied here. These results agree with those of Rosenkranz (1990), who found that the development period from egg laying until cell sealing was shorter in Africanized bees than in $A m$ carnica when compared side by side. However, when this difference occurred has not been determined.

The characterization of the different pupal stages presented here is similar to that reported by Jay (1962) and Rembold et al (1980). However, as also observed in the larval phase, the duration of these stages differs slightly when we compare our data with those reported for $A m$ carnica (Rembold et al, 1980). The major differences reside in the white-eyed pupal stage ( $\mathrm{Pw}$ ), which is $\approx 36 \mathrm{~h}$ for Africanized bees and $42 \mathrm{~h}$ for $A m$ carnica (Rembold et al, 1980 ), and in the brown-eyed pupal stage $(\mathrm{Pb})$ which lasts 42 and $48 \mathrm{~h}$ in the 2 subtypes, respectively. Thus, the total duration of the preimaginal stages is $24 \mathrm{~h}$ shorter in Africanized honey bees than in $A \mathrm{~m}$ carni$\mathrm{ca}$, with a variation of $6 \mathrm{~h}$. Therefore, according to these results, as well as those of others authors (Garofalo, 1977; Couto, 1987; Rosenkranz, 1990) the duration of postembryonic development of Africanized bees is shorter than in European bees. Our results show that this difference is not due to the absence of certain stages but rather to the shorter duration of some stages during development. When compared to African bees, $A m$ adansonii (Tribe and Fletcher, 1977), and $A m$ scutellata (Moritz, 1985), Africanized bees have a slightly longer total duration of pregimaginal stages, a difference of $\approx 18$ to $24 \mathrm{~h}$. On this basis, Africanized bees may be considered to occupy a position between European and African bees.

The degree of hybridization in Africanized bees has been determined on the ba- 
sis of different parameters such as isozyme frequency (Del Lama et al, 1988; Lobo et al, 1989), morphometry (Buco et al, 1987; Daly, 1991), analysis of mitochondrial DNA (Smith et al, 1989; Smith, 1991), and estimates of gene flow among the various European and Africanized populations (Sheppard and McPheron, 1986; Rinderer et al, 1991; Sheppard et al, 1991). According to these investigators, the effects of hybridization vary with the intensity of gene flow in the different populations; that is, the degree of hybridization is related to the interrelationships among these populations at the limits of their distributions. We would therefore expect a variation in the duration of pre-imaginal development in Africanized bees related to the degree of hybridization that has occurred in the different regions of their geographic distribution. Further studies in regions where the different degrees of hybridization have been studied (Sheppard et al, 1991) in transition areas will be needed to test this hypothesis.

\section{ACKNOWLEDGMENTS}

We are indebted to $\operatorname{Pr} Z \mathrm{~L}$ Simoes for helpful suggestions during the study and for the reading of the manuscript, and to $Z$ Schiavoni and $L$ Aguiar for technical assistance. This investigation was supported by the CNPq (Brazilian National Research Council).

\section{Résumé - Caractérisation des stades} de développement préimaginal chez les ouvrières de l'abeille africanisée (Apis mellifera $\mathrm{L}$ ). Le développement préimaginal d'Apis mellifera a déjà été décrit par plusieurs chercheurs et l'existence de 5 stades larvaires consacrés à l'alimentation et à la croissance est bien établie. Le dernier stade larvaire peut être subdivisé en diverses périodes, qui impliquent une série de modifications morphologiques et phy- siologiques en liaison avec la métamorphose. Plusieurs stades ont également été observés pendant la phase nymphale. Diverses études ont montré que la durée des stades des phases larvaire et nymphale varie d'une race d'abeilles à l'autre. Nous avons étudié en détail ces 2 phases du développement préimaginal chez des abeilles africanisées récoltées à Ribeirao Preto, SP, Brésil, et caractérisé les divers stades ainsi que leur durée.

Grâce à un suivi de la ponte, nous avons prélevé des échantillons toutes les $6 \mathrm{~h}$, du 1er stade larvaire jusqu'à l'émergence de l'adulte. Les stades larvaires ont tout d'abord été caractérisés par le poids du corps et le diamètre de la tête (fig 1). Ces mesures ont permis de reconnaître 5 groupes, correspondant chacun à un stade larvaire. Les mesures ont porté sur un total de 1249 ouvrière. Le $5^{\mathrm{e}}$ stade larvaire a été caractérisé par des paramètres supplémentaires, tels que la défécation, la position de la larve dans la cellule et la longueur tibio-tarsale des pattes postérieures. Ces subdivisions ont été classées en 3 périodes d'alimentation (LF1, LF2, LF3) et 3 périodes d'operculation (LS1, LS2, LS3). En LF1, la larve pèse environ $35 \mathrm{mg}$ et à la fin de LF3, qui est le moment où la cellule va être operculée, elle atteint $120 \mathrm{mg}$. Au stade LS1, la larve est encore enroulée à l'intérieur de la cellule. Elle s'étire progressivement et diminue ses mouvements au cours de LS2 et LS3. La défécation a lieu durant ces stades. En LS1, l'intestin est complètement rempli, la défécation proprement dite commence en LS2 et se poursuit en LS3. La longueur tibio-tarsale est de 0,8 à $1 \mathrm{~mm}$ en LS1 et reste inchangée jusqu'à la fin de LS3. La période prénymphale (stades PP) commence lorsque l'intestin est complètement vide, la nymphe immobile et que l'apolyse commence dans la région céphalique. La longueur tibiotarsale passe à 1,20-1,44 mm (PP1). En $P P 2$, elle augmente jusqu'à $1,80-2,00 \mathrm{~mm}$ 
et reste inchangée en PP3. L'apolyse progresse et culmine au moment de la mue nymphale à la fin de PP3.

Des échantillons de nymphes ont également été prélevés toutes les $6 \mathrm{~h}$ à partir d'une ponte contrôlée et 7 stades (tableau III) ont été caractérisés d'après la couleur de l'œil et celle du thorax.

Par cette caractérisation, on a pu ainsi déterminer la durée des stades (fig 3), avec une précision de $6 \mathrm{~h}$. Si l'on compare les stades décrits ici avec ceux décrits pour les abeilles européennes, on trouve peu de différences dans la durée des 4 premiers stades larvaires. Au $5^{\mathrm{e}}$ stade pourtant, on s'aperçoit que la période LF3 (operculation de la cellule) est plus courte d'environ $6 \mathrm{~h}$ chez l'abeille africanisée. Le même phénomène se produit pour les prénymphes. D'autres différences sont visibles aux stades $\mathrm{Pw}$ et $\mathrm{Pb}$ pendant la phase nymphale, chaque stade étant plus court de $6 \mathrm{~h}$ par rapport à l'abeille européenne ( $A m$ carnica). La différence totale atteint environ $24 \mathrm{~h}$, et cela n'est pas dû à l'absence de stades, mais plutôt à la durée réduite de certains d'entre eux. Comparée aux abeilles africaines, la durée du développement pré-imaginal des abeilles africanisées est plus longue d'environ $24 \mathrm{~h}$. De ce point de vue, les abeilles africanisées semblent donc occuper une position intermédiaire entre les européennes et les africaines.

\section{abeille africanisée / développement post-embryonnaire / durée de dévelop- pement / stade larvaire}

\section{Zusammenfassung - Charakterisie- rung der präimaginalen Entwicklungs- stadien bei Arbeiterinnen der afrikani- sierten Honigbiene (Apis mellifera L).} Die präimaginale Entwicklung von Apis mellifera wurde schon von mehreren Forschern beschrieben. Es wurden fünf larva- le Häutungsstadien festgestellt, mit den vorwiegenden Aktivitäten des Fressens und des Wachstums. Das letzte larvale Stadium kann in verschiedene Perioden unterteilt werden, die mit einer Serie von morphologischen und physiologischen Veränderungen im Zuge der Metamorphose zusammenhängen. Auch in der Puppenphase können mehrere Stadien beobachtet werden. Einige Studien haben Unterschiede in der Länge der Larven- und Puppenstadien bei verschiedenen Bienenrassen gezeigt. Wir haben diese beiden Phasen der präimaginalen Entwicklung bei afrikanisierten Bienen aus Ribeirao Preto (SP, Brasilien) untersucht und die verschiedenen Stadien sowie deren Dauer beschrieben.

Die Proben wurden unter kontrollierter Eiablage in 6-stündigen Intervallen vom ersten Larvenstadium bis zum Schlüpfen der Biene gesammelt. Die Larvenstadien wurden zunächst nach ihrem Körpergewicht und dem Kopfdurchmesser (Abb 1) charakterisiert, wobei fünf Gruppen entsprechend jeder Häutung festgestellt werden konnten. Insgesamt wurden 1249 Arbeiterinnen gemessen. Das 5.Stadium wurde nach zusätzlichen Merkmalen, wie Defäkation, Lage der Larve in der Zelle und Tibio-Tarsallänge des Hinterbeins unterteilt. Diese Unterteilungen wurden als die folgenden Perioden klassifiziert: Freßperiode 1, 2 und 3 (LF1, LF2, LF3). Während der LF1 wiegt die Larve ungefähr 35 mg; am Ende von LF3, zur Zeit der Zellverdeckelung, erreicht sie $120 \mathrm{mg}$. LS1, LS2 und LS3 entsprechen den Perioden ab Beginn der Zellverdeckelung. Während LS1 liegt die Larve noch eingerollt in der Zelle. Während der Perioden LS2 und LS3 streckt sie sich in der Zelle allmählich aus und sie verringert ihre Bewegungen. Während dieser Perioden erfolgt die Defäkation. Während LS1 ist der Darm noch vollständig gefüllt, die eigentliche Defäkation beginnt während LS2 und schreitet wäh- 
rend LS3 fort. Die Tibio-Tarsallänge beträgt während LS1 $0.8-1.0 \mathrm{~mm}$ und bleibt bis zum Ende von LS3 unverändert. Die Vorpuppenperiode beginnt, sobald der Darm vollständig leer ist; die Puppe liegt völlig bewegungslos, und die Apolyse beginnt in der Kopfregion. Die TibioTarsallänge vergrößert sich auf 1.20-1.44 mm (PP1). Während der PP2 wächst die Tibio-Tarsallänge auf $1.80-2.00 \mathrm{~mm}$, aber während PP3 bleibt sie unverändert. Die Apolyse schreitet fort und erreicht in der Puppenhäutung am Ende von PP3 ihren Höhepunkt.

An den in 6-stündigen Intervallen ab der kontrollierten Eiablage gesammelten Proben konnten nach der Farbe von Augen und Thorax 7 Puppenstadien unterschieden werden (Tabelle III).

Auf der Grundlage dieser Klassifizierung konnte die Dauer der verschiedenen Stadien mit einer Genauigkeit von 6 Stunden bestimmt werden (Abb 3). Bei dem Vergleich mit den Angaben über europäische Rassen bestanden für die ersten vier Larvenstadien nur geringe Unterschiede. Für das 5.Stadium ergab sich jedoch bei der Periode LF3 (Zellverdeckelung) für unser Material eine Verkürzung von 6 Stunden, und dasselbe war bei den Vorpuppen festzustellen. Unterschiede waren auch während der Puppenphase bei den Perioden $\mathrm{Pw}$ und $\mathrm{Pb}$ zu beobachten, die jede um 6 Stunden kürzer waren als bei europäischen Rassen ( $A m$ carnica). Es ergab sich ein Gesamtunterschied von 24 Stunden, der aber nicht durch das Fehlen von Häutungsstadien entstand, sondern vielmehr durch die Verkürzung jedes einzelnen Stadiums bei den afrikanisierten Bienen. Bei einem Vergleich mit originalen afrikanischen Bienen war die präimaginale Entwicklung der afrikanisierten Bienen etwa um 24 Stunden länger. Es scheinen also die afrikanisierten Bienen in dieser Hinsicht eine Mittelstellung zwischen euro- päischen und afrikanischen Bienen einzunehmen.

\section{Afrikanisierte Biene / Präimaginale Ent- wicklung / Entwicklungsdauer / Larvale Stadien}

\section{REFERENCES}

Bertholf $L M$ (1925) The moults of the honeybee. $J$ Econ Entomol 18, 380-384

Buco SM, Rinderer TE, Silvester HA, Collins AM, Lancaster VA, Crewe RM (1987) Morphometric differences between South American Africanized and South African (Apis mellifera scutellata) honey bees. Apidologie 18, 217-222

Couto LA (1987) Efeito do fornecimento de raçöes sobre a produçäo de cria e alimento e sua herdabilidade em colmeias de Apis mellifera infestadas com o ácaro Varroa jacobsoni. MS thesis, Facultade de Ciências Agrárias e Veterinária de Jaboticabal, UNESP, $132 \mathrm{pp}$

Daly HV (1991) Systematics and identification of Africanized honey bees. In: The "African" Honey Bee (Spivak M, Fletcher DJC, Breed MD, eds) Westview Press, Boulder, CO, 13-44

Del Lama MA, Figueiredo RA, Soares AEE, Del Lama SN (1988) Hexokinase polymorphism in Apis mellifera and its use for Africanized honeybee identification. Rev Bras Genet 11, 287-297

Fletcher DJC (1978) The Africanized honey bee, Apis mellifera adansonii in Africa. Annu Rev Entomol 23, 151-171

Garofalo CA (1977) Brood viability in normal colonies of Apis mellifera. J Apic Res 16, 3-13

Goitein MRC (1989) Estudos morfológicos e morfométricos do corpo gorduroso e enócitos de Apis mellifera L (Hymenoptera, Apidae) durante o desenvolvimento larval. MS thesis, Instituto de Biociências, UNESP, Rio Claro, $77 \mathrm{pp}$

Hinton HE (1973) Neglected phases in metamorphosis: a reply to VB Wigglesworth. $J E n-$ tomol (A) 48, 57-68

Hutchinson GE, Tongring N (1984) The possible adaptative significance of the Brook-Dyar rule. J Theor Biol 106 (3), 437-439 
Jay SC (1962) Colour changes of honeybee pupae. Bee World 43, 119-122

Jay SC (1963) The development of honeybees in their cells. J Apic Res 2, 117-134

Kerr WE, Gonçalves LS, Blotta LF, Maciel HB (1970) Biologia comparada entre as abelhas italianas (Apis mellifera ligustica) africanas (Apis mellifera adansonii) e suas hibridas. In: Anais do $1^{\circ}$ Congresso Brasileiro de Apicultura. Florianopolis, SC, 151-185

Lobo JA, Del Lama MA, Mestriner MA (1989) Population differentiation and racial admixture in the Africanized honeybee (Apis mellifera L). Evolution 43, 794-802

Morini MSC (1990) Capacidade reprodutiva de rainha de Apis mellifera L (Hymenoptera, Apidae) e sua relaçäo com alguns fatores ambientais. MS thesis, Instituto de Biociências, UNESP, Rio Clao, $155 \mathrm{pp}$

Myser WC (1954) The larval and pupal development of the honeybee, Apis mellifera Linnaeus. Ann Entomol Soc Am 47, 683-711

Moritz RFA (1985) Heritability of the postcapping stage in Apis mellifera and its relation to varroatosis resistance. $J$ Hered $76,267-270$

Munsell Book of Color (1976) Neighboring Hues Edition, Matte Finish Collection. Macbeth Div, Kollmorgen Corp, Baltimore, MS

Nelson JA (1924) Morphology of the honeybee larva. J Agric Res 28, 1167-1213

Palacio MA (1991) Efeito da inseminaçäo instrumental e da endogamia na dinâmica de populaçöes de abelhas européias e africanizadas e na migraçäo de espermatozóides para a espermateca de rainha de Apis mellifera $L$. MS thesis, Faculdade de Medicina de Ribeiräo Preto, USP, $162 \mathrm{pp}$

Rachinsky A (1990) Juvenilhormon und Ectysteroide in der Kastenentwicklung der Honigbiene (Apis mellifera L). Diss Erlangung des Grades eines Doktors der Naturwissenschaften der Fakultät für Biologie der Eberhard Karls-Universität Tübingen
Rembold H, Kramer JP, Ulrich GM (1980) Characterization of postembryonic developmental stages of the female castes of the honey bee, Apis mellifera L. Apidologie 11, 29-38

Rinderer TE, Stelzer JA, Oldroyd BP, Buco SM, Rubink WL (1991) Hybridization between European and Africanized honey bees in the neotropical Yucatan peninsula. Science 252, 309-311

Rozenkranz P (1990) Wirtsfaktoren in der Steurung der Reproduktion der parasitischen Bienenmilbe Varroa jacobsoni in Völkern von Apis mellifera. Diss Erlangung des Grades eines Doktors der Naturwissenschaften der Fakultät für Biologie der Eberhard Karls Universität Tübingen

Sheppard WS, McPheron BA (1986) Genetic variation in honey bees from an area of racial hybridization in western Czechoslovakia. Apidologie 17, 21-32

Sheppard WS, Rinderer TE, Mazzoli J, Shimanuki H, Stelzer JA (1991) Gene flow between African and European derived honey bee populations in Argentina. Nature 349, 782784

Smith DR (1991) African bees in the Americas: insights from biogeography and genetics. Trends Ecol Evol 6, 17-21

Smith DR, Brown WM, Taylor OR (1989) Neotropical Africanized honeybees have African mitochondrial DNA. Nature 321, 674-679

Thrasyvoulou AT, Benton AW (1982) Rates of growth of honeybee larvae. J Apic Res 21, 189-192

Tribe GD, Fletcher DJC (1977) Rate of the development of the workers of Apis mellifera adansonii in Africa. In: African Bees: Their Taxonomy, Biology and Economic Use (Fletcher DJC, ed) Pretoria, South Africa; Apimondia, 115-119

Wang DI (1965) Growth rates of young queen and worker honeybee larvae. J Apic Res 4, 3-5 